\title{
THE FASTENERS PRESSING TECHNOLOGY IN THIN-WALLED STRUCTURES
}

\begin{abstract}
Nowadays, in the thin-walled structures industry a dynamic development of the assembling technologies is observed. This development is caused by the ensuring of the manufacturing processes competitiveness. The mounting process, with the use of the constructional connections, is often the structure and quality construction last phase. The thin-walled fragments of the larger structures often have different tasks to satisfy. Sometimes, the performance of the structure requires the use of not only permanent joints but also use of the temporary fastening. The temporary fastening allows for easier positioning and for their removal during repairs or maintenance. This paper presents the importance of the pressed fasteners use in the thinwalled structures during the assembly processes. The typical fasteners structures and the selected special solutions were presented. The bind rivet nut basic solutions and their assembling technologies were described.
\end{abstract}

Keywords: fasteners, blind rivet nut pressing, sheets joining, thin-walled structures

\section{Introduction}

The mounting process, with the use of the constructional connections, is often the structure and quality construction last phase. In the most cases the commercial manufacturing of the finished products would be impossible, without the use of the various technologies during the assembly processes [1]. The individual parts joining processes allow to create the functional spatial forms (fig. 1.). Still popular, in the assembly processes, are temporary fastening technologies (with screws and bolts use). The temporary fastening technologies enable to connect and disconnect the assembled parts without damaging them or damaging fasteners.

In the thin-walled sheet metal elements it is often necessary to apply temporary fastening during the assembly process $[2,3]$. This temporary fastening solution is the fasteners with the thread. Due to the very small thickness of the con-

\footnotetext{
${ }^{1}$ Autor do korespondencji/corresponding author: Jacek Mucha, Rzeszow University of Technology, 8 Powstańców Warszawy Avenue, 35-959 Rzeszow, Poland, tel.: (17) 8651636, e-mail: j_mucha@prz.edu.pl
} 
nected elements, there is the need to make appropriate thread length, in a particular place, to ensure adequate joint load capacity. Generally, there are three joining methods:

- extract the hole rim and cut the thread on the formed cylindrical part (fig. 2a),

- welding the additional fastener (fig. $2 b$ ),

- plastic deformation of the fastener or joined sheet material (fig. 2c).

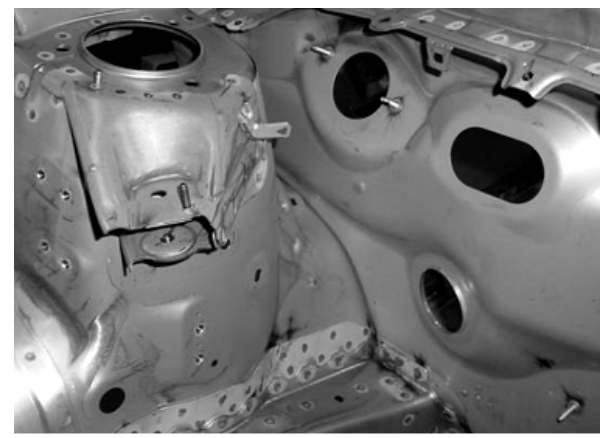

Fig. 1. Part of the motorcar body structure manufactured using the different assembly technologies

The first method allows to obtain direct screw joint, while the other two allow to obtain the indirect screw joint (with additional threaded elements). Each of these methods requires a different process technology, different mounting devices and in two last mentioned methods the additional fastener. The thinwalled construction designers define the joints strength requirements. Then the appropriate joining method for this task is selected. Moreover, the axis load capacity and the torsional load capacity are also required. Therefore, it is essential to press the fastener in the sheet material appropriate to avoid its rotation (fig. 3.), during the final assembly process (tightening).

a)

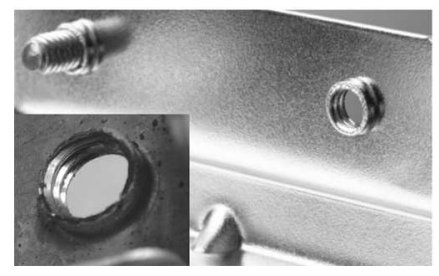

b)

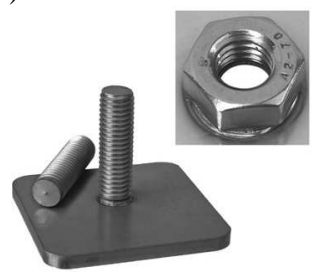

c)

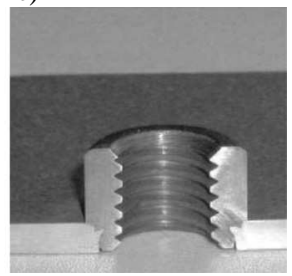

Fig. 2. The basic solutions of the thread connections in the sheet metal structures: a) thread cut in the sheet material, b) the additional part with thread welded with sheet, c) the blind rivet nut with internal thread 
Over time, the normal joining technology, by threaded connection, evolved and it is still changing (fig. 4.). It was caused by new requirements [4-6]. These days, a design solution variety is very large. Some parts of the fastener are similar to each other, and they are characterized by the same joining technology and their applications. Depending on the manufacturer they may differ in small details. Therefore, the most important and interesting technologies were presented.

Fig. 3. The fastener main load; 1 - the connecting element, 2 - the additional fastener, 3 - the washer, 4 - the material with mounted fastener, 5 - the additional bolted material

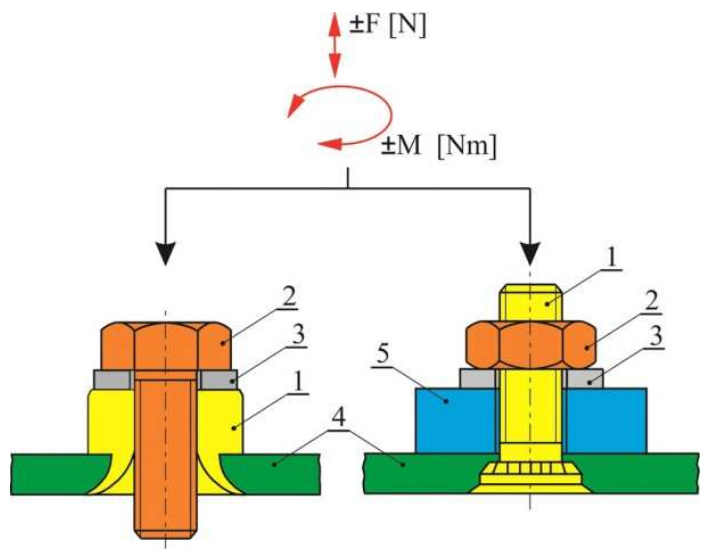

a)

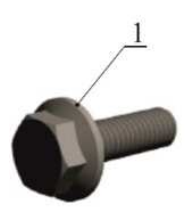

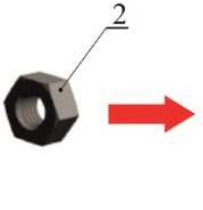

b)

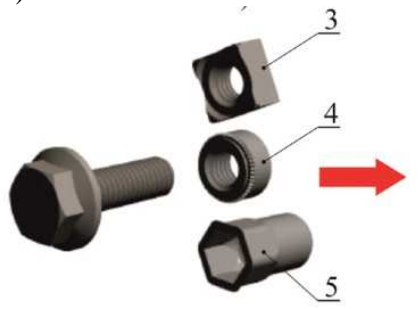

c)

Fig. 4. The thread fasteners development: a) the classic bolted joint, b) the combination of the bolts and the pressed elements, c) the solutions in the case of the construction with closed spaces; 1 - the bolt, 2 - the classic nut, 3-5 - the blind rivet nut

\section{Fasteners used in the pressing technology}

During the structural connections designing many factors are taken into account, and the most important, which determinate the design process, are:

- the geometry, structure and product material,

- the required joint mechanical properties,

- the assembly process,

- the reliability, durability and safety,

- the economics of the joining method, 
- the special requirements,

- the intensity of the mechanical and chemical interactions on the joint,

- the knowledge obtained from the previous design concepts of the new solutions.

Taking into account these factors the fastener design and the assembly process technology are developed. The pressed fasteners have grooves for the filling the sheet material. Depending on their shape and their location they can be blocked during the assembly process in the different way. From the point of the main groove shape and the additional notched grooves view the several fundamental design solution of the pressed nut can be distinguished (fig. 5.). The main groove, which is filled by joined material, may have different shape from rectangular to the cylindrical part (fig. 5c), triangular profile (fig. 5d) and more complex shape (fig. 5a, b). The additional notched grooves may be formed on the cylindrical part of the fastener before the main groove (fig. 5a) or after the main groove (fig. 5b). To ensure the efficient flow of the material in the groove space, which is blocking the axial rotation and movements of the nut, the main groove can have a sloped internal surfaces fragments. The notched grooves

a)

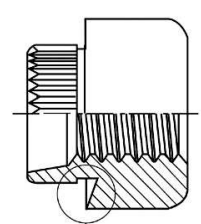

A b)
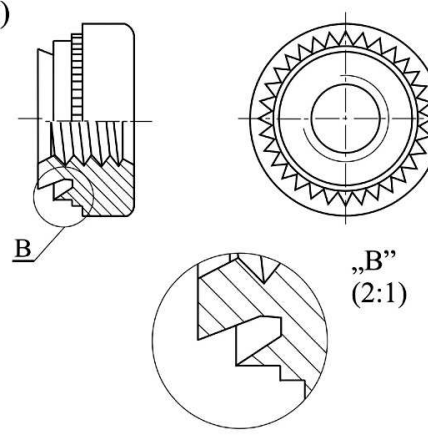

d)

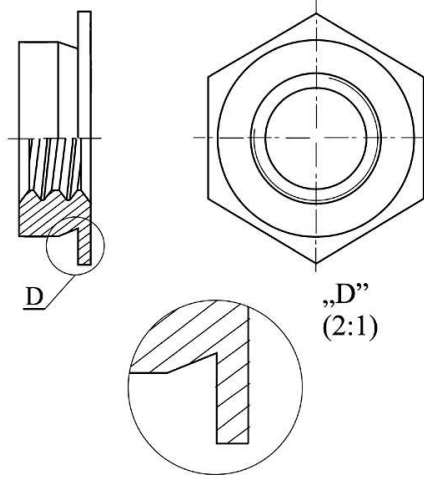

c)

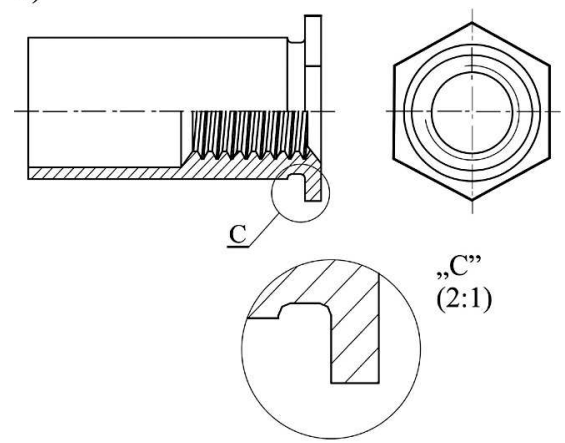

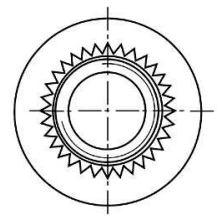

,A"

(2:1)
B

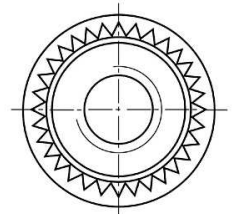

"B"

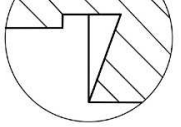

. 
(fig. 5a, b) are generally intended to increase the torque moment resistance (fig. 3.). There are a huge variety of fastener solutions and the most commonly used are presented in fig. 6 .

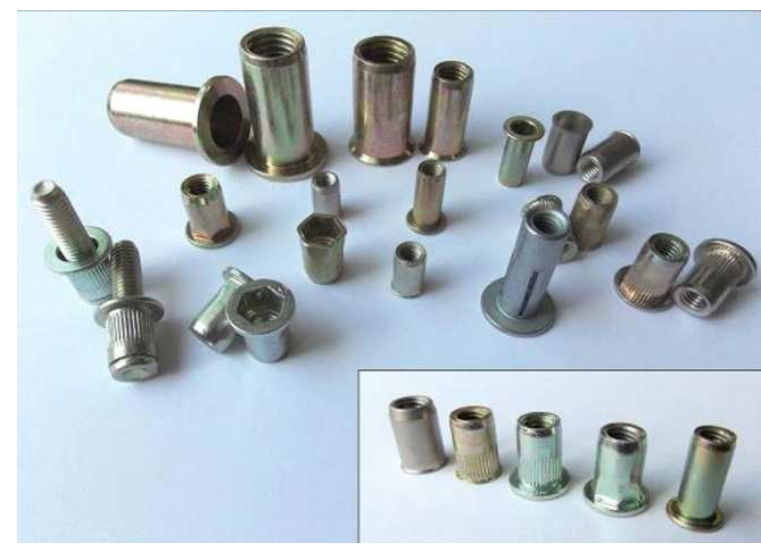

Fig. 6. The fastener examples used in the thin-walled constructions during the assembly process

a)

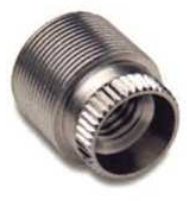

d)

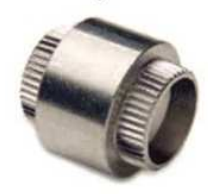

b)

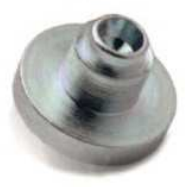

e)

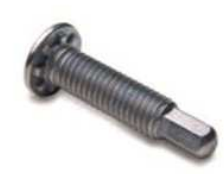

c)

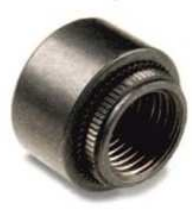

f)

Fig. 7. The fastener special solutions

Many types of these elements have a special structure, so they can comply tasks, which are results of their design. Some of them, developed by Kerb Konus Company, are presented in the fig. 7. The pressed fastener can have internal and also external thread (fig. 7a), which increase possibilities of their using. For ensuring for example other element centering or to increase the load surface the part of the fastener cylindrical surface can be enlarged (fig. $7 \mathrm{~b}$ ). To increase the torsion moment resistance the notched grooves are also placed on the front and the cylindrical surface (fig. 7c). By using the double-sided blind rivet nut the 
distance between joining sheets can be determined (fig. 7d). The elements with special hexagonal structure (fig. 7e) or with holes and additional ridges (fig. 7f) ensure the possibilities of the bolt fixing during the tighten up a nut.

\section{The pressing technology}

Engineers designing assembly processes regularly use the self-locking fasteners technology (self-clinching - SC), when they need to apply the thread function in the thin sheets. The main indicators, which determine the suitability of the joining technology, in the assembling technology economics aspects, are: manufacturing time, energy consumption, producibility.

The SC technology offers especially time and cost savings. The fastener installation is performed by pressing it by manual or fully automatic systems. The fastener pressing process can be performed for galvanized or for paint coated elements, without damaging the coating. Even for sheet thickness $0.5 \mathrm{~mm}$ it is possible to press the fastener. It determines opportunities of structure weight reduction. The process time for manual hand tools is $2-3 \mathrm{~s}$, and for automated assembly systems is about 4-6 s.

Many factors should be taken into account when the joining technology is selected. One of them is the external forces (loads) resistance of the sheet structure. For the mass production the joining system should be able to automate. For each case of the fastener structure the pressing method is relatively simple [7]. There are two basic methods of anchoring the fasteners:

- inserting in the hole and blocking it by fastener deformation (fig. 8.),

- sheet material deformation (figs. 9. and 10.).

The fastener mounting consists in the sheet material flow (caused by high pressure load), which results in an element blockage. In the most cases the hole for the fastener must be previously performed. However, they are same kind of the blind rivet nut which firstly punched a hole and then they are blocked. There are three groups of the threaded fasteners: with the internal thread inside the through hole (figs. 8. and 9.), with the internal thread inside the blind hole (fig. 10.), and with the external thread (fig. 11.). In two last fastener cases the pressing process is the same in practice. Part of the fasteners is pressed to make a flat surface on the both side of the sheet material (fig. 12.).

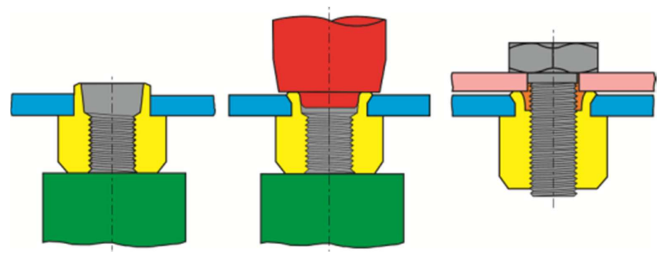

Fig. 8. The connector obtaining by plastic deformation of the blind rivet nut 

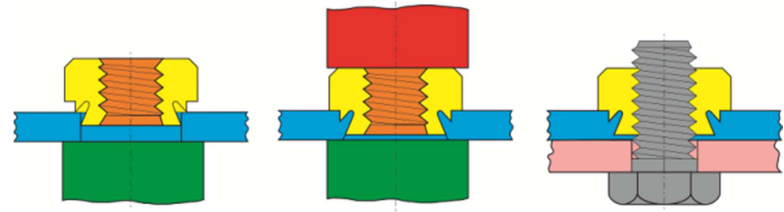

Fig. 9. The joint formation involving the sheet material plastic deformation
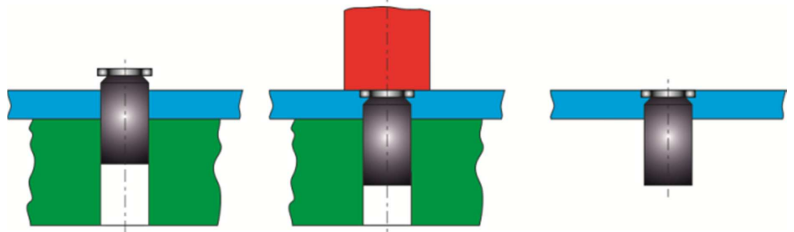

Fig. 10. The idea of the fastening a thread fastener in a blind hole
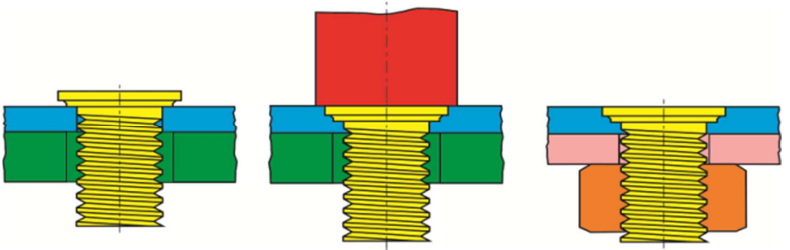

Fig. 11. The bolt form fastener mounting
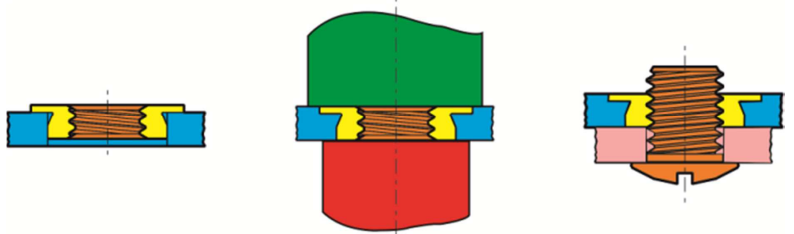

Fig. 12. Fasteners pressed to make a flat surface on the both side of the sheet material

The fastener mounting process can be performed by using manual hand tools (fig. 13a) or by using automated assembly stand with the press, the loader (fastener separator) and with the industrial robot (fig. 13b). The blind rivet nut position, in the automated assembly stands, is depended on the fastener loading system and depended on the die and the punch system (fig. 14.). The fastener loading systems are:

- rotary loader for inserting the fastener in the lower punch socket (fig. 14a),

- loader inserting fastener directly into the punch head from the punch side (fig. 14b). 
a)

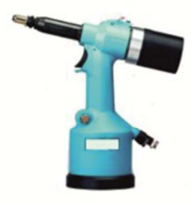

b)

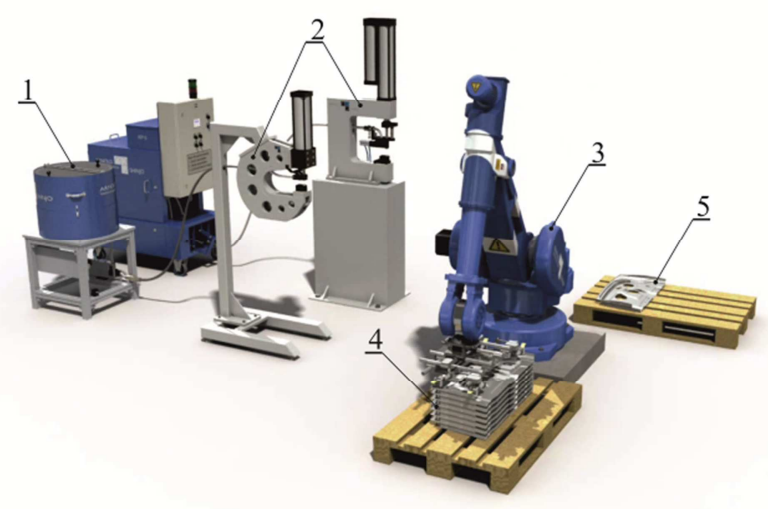

Fig. 13. The joining systems: a) manual, b) fastener automated assembly stand; 1 - the fastener separator, 2 - the press with the C-frame, 3 - the industrial robot, 4 - the sheet material part for joining, 5 - the part with the pressed fastener

Depending on the main groove shape (fig. 5.) the flat punch or the die with appropriate ridge shape (fig. 15.) can be used as a lower tool. The sheet material flow intensity and the fastener blocking method depend on the groove and ridge shape combination. Its proper matching is related to the sheet material and to the axial load force. The additional notched grooves block the fastener relative rotation (fig. 3.). For other fasteners, such as bolts, this differentiation is obtained by the size and the shape of the groove next to the head and by special notched grooves (fig. 16.).

a)
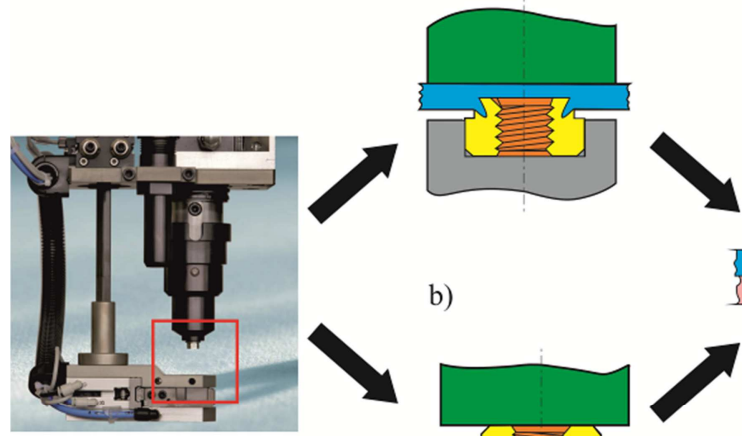

b)
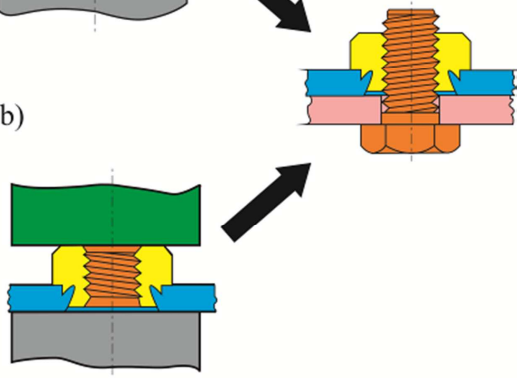

Fig. 14. The nut feed variants and the tools shape: $a, b-$ explanation in text 
Fig. 15. The lower tools surface variants; 1 - the pressed nut, 2 - the ridge on the lower tool, 3 - the sheet material, 4 - the lower tool

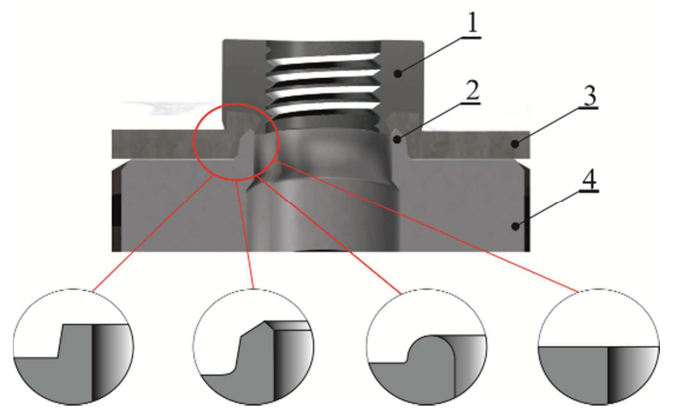

Fig. 16. The bolt head variations; 1 - the sheet material, 2 - the die, 3 - the bolt

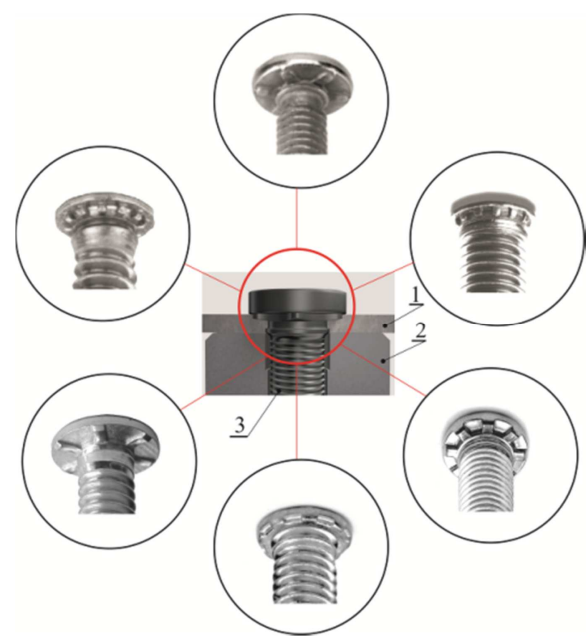

\section{The applications examples}

The use of the SC technology includes the sheet metal structure industry, such as: automobile, electronics and aircraft industry. The pressed fasteners in the thin-walled structures allow for easy assembly by using the screw joint function. The blind rivet nuts are used in the desktop frames (fig. 17a). They can also be used in more responsible elements, for example the Kerb Konus company blind rivet nut in the car body structure (fig. 17b). Not only nuts but also special bolts are pressed in the sheet material parts (fig. 16.). Similar applications are related to part assembling (fig. 18.). In the case of the special bolts or pins, to block their rotation, on the head lower surface they have specially radial arranged grooves. In the thin-walled structures parts assembling the rectangular nuts are also used (fig. 19.). 
a)

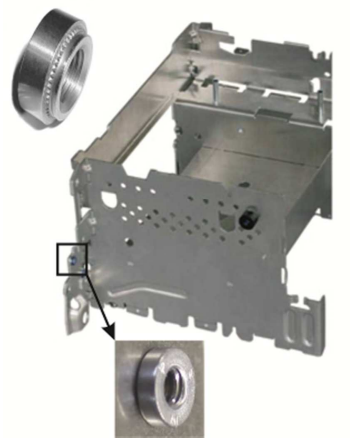

b)

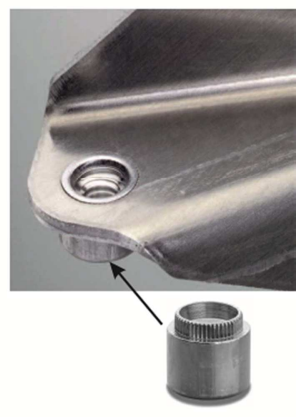

Fig. 17. The examples of the blind rivet nuts used in the sheet metal constructions: $\mathrm{a}, \mathrm{b}$ - explanation in text

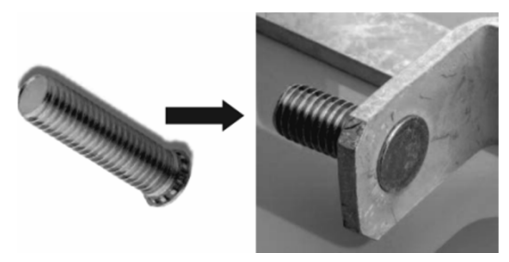

Fig. 18. The application example of the Kerb Konus company bolts

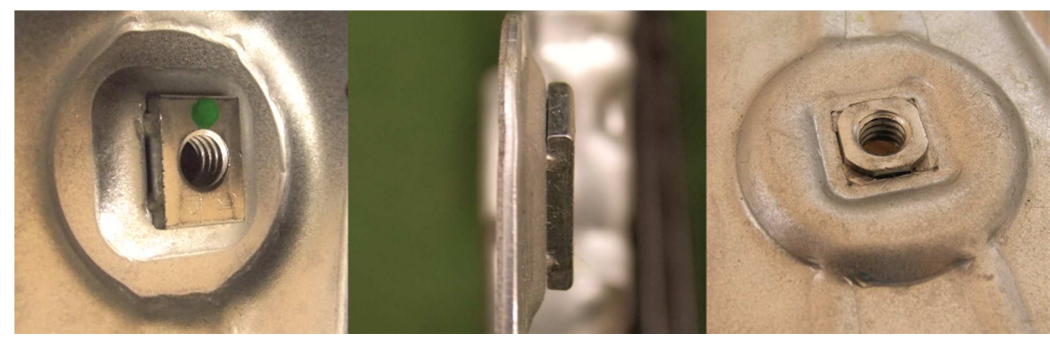

Fig. 19. The rectangular nut pressed in the vehicle window lifting element

Depending on the fastener design (fig. 5. and 6.) and pressing process a required torque moment resistance is obtained. It is important to block properly fastener rotation during the tightening up a screw or a bolt. Hence, the fastener structures with cylindrical surface and with additional notched grooves (fig. 20a) or with a shape other than round (fig. 20b) can be distinguished. The fastener can be blocked in both sides of its flanges (fig. 20.) or on the flat surface side (fig. 21.) [8]. This first solution allows to join axial loading in two directions, while the second solution only in one direction. In the case of high sensitivity to the material pressure (potential material failure) the blind rivet nut with the cut cylindrical flange can be used (fig. 22.). This reduces the upsetting forces, but the axial load pressures are greater (the smaller surface contact). Solutions of this type are often used in the case of the plastics joining. 
a)

b)
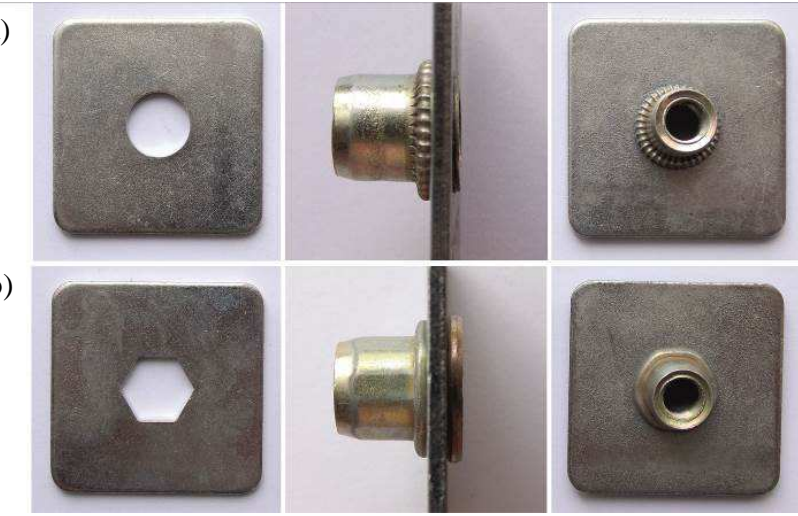

Fig. 20. The Böllhoff company joints for the round hole (a) and for the hexagonal hole (b)

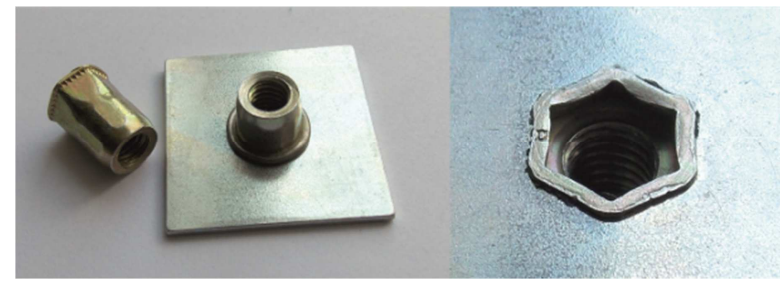

Fig. 21. Blind rivet nut with unilateral upset in the hexagonal hole

The pressed blind rivet nut can be used with providing the tools support and the both-sided tool access to the joint. Some fasteners solutions ensure possibilities of pressing them in the elements with one-side tool access (fig. 23.). For ensuring a good sealing in the joint an additional sealing element should be placed (fig. 23b). It is very common situation during the automotive body panels assembling. A number of closed profiles do not allow to use the blind rivet nuts.

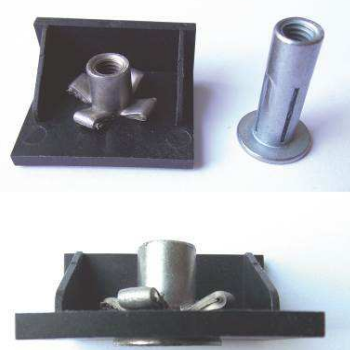

Fig. 22. Blind rivet nut with cut cylindrical flange 
a)
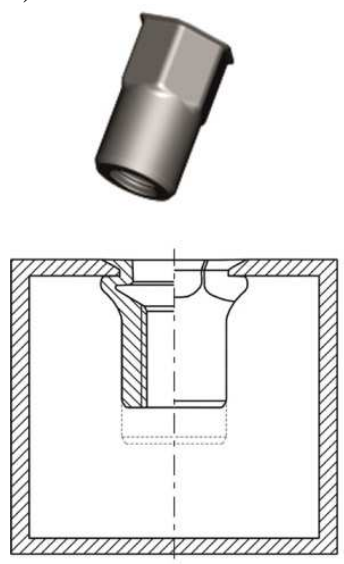

b)
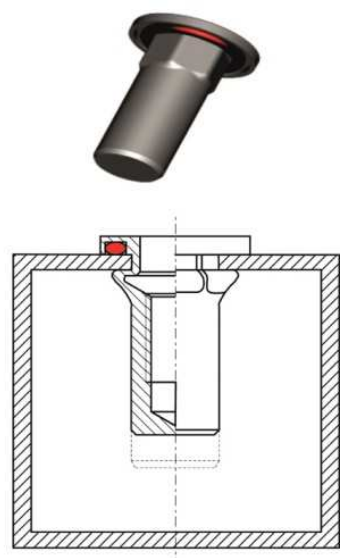

Fig. 23. The example of the threaded sleeves using in the closed profile: a) simple solution, b) solution with the sealing element

\section{Conclusions}

In this paper an overview of the fastener pressing technology in the thinwalled structures was presented. Additional fasteners allow sheet metal product easier assembling. The pressed elements are selected according to the joints functions. The manufacturers, especially in the automotive industry increase the use of this joining technology. In the case of the need to maintain a flat surface after the fastener pressing, a special structure development provides these possibilities. The tools and the pressed fastener passer head are not complicated and they are similar to the rivet passer head. To ensure the tightness, the pressed elements have additional sealing rings, or to increase the torque moment resistance an adhesive is inputted. A large number of fasteners offered by many companies provide greater opportunities of the thin-walled sheet metal structures assembling.

\section{References}

[1] Bałon P., Świątoniowski A.: Porównanie procesu łączenia podczas formowania oraz zgrzewania dla elementów struktury samochodu. Mechanik, 5-6 (2014), 364-375 .

[2] Bałon P., Świątoniowski A.: Stamping automotive parts with clinch nut process, AIP Conference Proceedings, 1567 (2013), 971-974.

[3] Mucha J., O znaczeniu połączeń konstrukcyjnych słów kilka. Stal Metale Nowe Technol., 9-10 (2011), 100-101.

[4] Kompleksowe osadzanie elementów złącznych. Artykuł reklamowy firmy Tox Pressotechnik, Stal Metale Nowe Technol., 5-6 (2013), 139. 
[5] Mucha J.: Nowoczesne rozwiązanie konstrukcji podkładki blokującej firmy Böllhoff - RIPP LOCK. Stal Metale Nowe Technol., 9-10 (2011), 125.

[6] Bober M.: Dobór łączników do montażu stalowych blach profilowych. Nowoczesne Hale, 1 (2012), 67-69.

[7] Elementy złączne do cienkich detali kształtowanych. Materiał reklamowy firmy Kerb Konus Vertriebs-GMBH, www.4metal.pl (dostęp: 04.04.2008 r.).

[8] Materiały reklamowe firmy Wilhelm Böllhoff GmbH \& Co. KG, www.boellhoff.com (dostęp: 30.07.2014 r.).

\title{
TECHNOLOGIA WTŁACZANIA ELEMENTÓW ZŁĄCZNYCH W CIENKOŚCIENNYCH KONSTRUKCJACH
}

\begin{abstract}
Streszczenie
Obecnie w przemyśle cienkościennych konstrukcji trwa dynamiczny rozwój technologii montażu związanych $\mathrm{z}$ zapewnieniem konkurencyjności procesów wytwarzania. Montaż, w którym wykorzystuje się połączenia konstrukcyjne, jest często ostatnim etapem budowy jego struktury, formy i jakości użytkowej. Cienkościenne fragmenty większej konstrukcji mają często do spełnienia różne zadania. Niekiedy wykonanie całościowe konstrukcji wymaga zastosowania połączeń nie tylko nierozłącznych, ale i rozłącznych. Połączenia rozłączne pozwalają na łatwiejsze pozycjonowanie względne łączonych elementów, ale i ich demontaż podczas napraw czy serwisowania. W pracy przedstawiono znaczenie rozwiązań elementów złącznych przeznaczonych do osadzania w cienkościennych konstrukcjach podczas montażu. Zaprezentowano typowe konstrukcje elementów złącznych oraz wybrane rozwiązania specjalne. Scharakteryzowano podstawowe rozwiązania nitonakrętek oraz technologie ich montażu.
\end{abstract}

Słowa kluczowe: elementy złączne, osadzanie nitonakrętek, łączenie blach, cienkościenne konstrukcje

DOI: $10.7862 / \mathrm{rm} .2014 .60$

Otrzymano/received: $15.09 .2014 \mathrm{r}$.

Zaakceptowano/accepted: 20.11.2014 r. 
